\title{
PRACTICABILITY OF COMPREHENSIVE CARE IN CLINICAL GENETICS IN THE BRAZILIAN UNIFIED HEALTH SYSTEM: EXPANDING THE DEBATE
}

\author{
Luís Carlos Lopes-Júnior', Milena Flória-Santos², Victor Evangelista de Faria Ferraz', Tereza Cristina Scatena \\ Villa ${ }^{4}$ Pedro Fredemir Palha ${ }^{5}$, Emiliana de Omena Bomfim ${ }^{6}$, Camila Aparecida Abrahão ${ }^{7}$, Sara da Silva ${ }^{8}$
}

\footnotetext{
${ }^{1}$ Master's student, Public Health Nursing Program, Universidade de São Paulo at Ribeirão Preto College of Nursing (EERP/ USP). Ribeirão Preto, São Paulo, Brazil. E-mail: luisgen@usp.br

2 Ph.D. in Sciences. Professor, Maternal-Infant and Public Health Nursing Department (DEMISP) at EERP/USP. Ribeirão Preto, São Paulo, Brazil. E-mail: milena@usp.br

${ }^{3}$ Ph.D. in Sciences. Professor, Department of Genetics, USP at Ribeirão Preto Medical School USP. Ribeirão Preto, São Paulo, Brazil. E-mail: victor.ferraz@gmail.com

${ }^{4}$ Ph.D. in Nursing. Full Professor, DEMISP/EERP/USP. Ribeirão Preto, São Paulo, Brazil. E-mail: tite@eerp.usp.br

${ }^{5}$ Ph.D. in Nursing. Associate Professor, DEMISP/EERP/USP. Ribeirão Preto, São Paulo, Brazil. E-mail: palha@eerp.usp.br

${ }^{6}$ Master's student in Nursing, Public Health Nursing Program, EERP/USP. Ribeirão Preto, São Paulo, Brazil. E-mail: emilianabomfim@usp.br

${ }^{7}$ Master's student in Nursing, Public Health Nursing Program, EERP/USP. Ribeirão Preto, São Paulo, Brazil. E-mail: camiusprp@ hotmail.com

${ }^{8}$ RN. Student, Professionalization Course, EERP/USP. Ribeirão Preto, São Paulo, Brazil. E-mail: sahra.silva@gmail.com
}

\begin{abstract}
This article aims to highlight the discussions on the National Policy for Comprehensive Care in Clinical Genetics and reflect on its pending regulation when genomic discoveries change the model of health care. Nine of the ten causes of morbidity and mortality worldwide presents genetic/genomic predisposition. Based on strategic planning, this Policy proposes the organization of a network of referral services and specialized centers in genetics, with capacity to meet the needs of the population. Its regulation requires training and qualification of the health care professionals to provide comprehensive care, to optimize access, to identify and diagnose individuals with increased risk for injuries with genetic predisposition early. In primary health care, the care in question should not be interpreted as a specialty, but as specialized. This model presents innovative perspectives, in line with the principles and guidelines of the Unified Health System.
\end{abstract}

DESCRIPTORS: Genetics. Genomics. Public health. Health policy.

\section{EXEQUIBILIDADE DA ATENÇÃO INTEGRAL EM GENÉTICA CLÍNICA NO SISTEMA ÚNICO DE SAÚDE: AMPLIANDO O DEBATE}

RESUMO: Este artigo tem por objetivo tornar proeminentes as discussões acerca da Política Nacional de Atenção Integral em Genética Clínica e refletir sobre sua pendente regulamentação, quando descobertas genômicas transformam o modelo de atenção à saúde. Nove dentre dez causas de morbimortalidade mundiais apresentam predisposição genética/genômica. Essa Política, fundamentada no planejamento estratégico, propõe a estruturação de uma rede de serviços de referência e centros especializados em genética, com capacidade para responder às necessidades da população. Sua regulamentação pressupõe capacitação e qualificação dos profissionais de saúde para oferecer atenção integral, otimizar o acesso, identificar e diagnosticar precocemente indivíduos com risco aumentado para agravos com predisposição genética. Na atenção básica à saúde, o cuidado em pauta não deve ser interpretado enquanto especialidade, mas como especializado. Esse modelo apresenta perspectivas inovadoras em consonância com os princípios e diretrizes modeladores do Sistema Único de Saúde.

DESCRITORES: Genética. Genômica. Saúde pública. Política de saúde. 


\title{
EJECUTABILIDAD DEL CUIDADO INTEGRAL EN GENÉTICA CLÍNICA EN SISTEMA ÚNICO DE SALUD: LA AMPLIACIÓN DEL DEBATE
}

\begin{abstract}
RESUMEN: Este estudio objetivó tornar prominentes discusiones acerca de la Política Nacional de Cuidado Integral en Genética Clínica y reflexionar sobre su regulación pendiente cuando descubrimientos genómicos transforman el modelo de atención a salud. Nueve entre diez causas de morbilidad y mortalidad en todo mundo presentan predisposición genética/genómica. La Política, fundamentada en la planificación estratégica, propone ofrecimiento de asesoramiento genético, mediante estructuración de una red de servicios de referencia y centros especializados, para satisfacer las necesidades de la población. Su regulación requiere capacitación y cualificación de profesionales de salud para ofrecer el cuidado integral, optimizar el acceso, identificar y diagnosticar precozmente individuos con mayor riesgo de enfermedades con predisposición genética. En la atención primaria de salud, el cuidado en cuestión no debe ser interpretado como una especialidad, pero sí como especializado. Este modelo presenta perspectivas innovadoras en consonancia con principios y directrices de los modeladores del Sistema Único de Salud.
\end{abstract}

DESCRIPTORES; Genética. Genómica. Salud pública. Política de salud.

\section{INTRODUCTION}

In the global context, health systems have been facing considerable challenges in view of the rapid advances in genomics. ${ }^{1}$ The mapping and sequencing of the human genome has led to an expansion in the research technologies that are being used to identify genetic and genomic factors, as well as to determine their influence on the populations' health. ${ }^{2}$ Information and technologies deriving from the Human Genome Project (HGP) can: a) improve the early identification of individuals and families with or at risk of presenting a genetic condition; b) establish interventions to reduce the risk, aiming to prevent problems; c) expand the genetic screening of individuals and families; d) support the prognosis and informed decision making of subjects with or at risk of genetic diseases; e) develop individual and personalized care; and f) use pharmacogenomics, through the selection and use of drugs based on individual genetic variations and the metabolic pathways of these drugs. ${ }^{1,3}$

Public health professionals need to start the translation process of these advances to the core of the health systems, in a responsible and problem-solving manner, with a view to expanding the health care and changing the focus from curative care to preventive strategies. ${ }^{1}$ This is the time to reconsider the prevention and treatment strategies the health systems are currently using, not remaining restricted to professionals but expanding the debate to the general public, public policy makers and other stakeholders in this scenario. ${ }^{1}$ In view of the advances highlighted by the HGP and the increased proportion of deaths that can be attributed to birth defects, ${ }^{4}$ currently the second cause of child mortality in Brazil, ${ }^{5}$ discussions have started to implement clinical genetics in the Unified Health System (SUS). ${ }^{6}$ In response to these discussions, the Ministry of Health proposed Decree GM/MS 81/2009, which established the National Policy for Comprehensive Care in Clinical Genetics (NPCCCG). ${ }^{7}$ The decree ratifies the need to structure, in the SUS, a regional and hierarchized service network that permits comprehensive care in clinical genetics and better access to that care. ${ }^{7}$ Nevertheless, the lack of regulation of the NPCCCG and, consequently, of the execution of its premises, makes the broad spectrum of actions this policy proposes ineffective, leaving them at the level of ideals.

The objective in this article is to highlight the discussions about the NPCCCG with a view to reflecting on the pending regulation of that policy.

\section{HEALTH POLICIES IN THE SHAPING OF THE UNIFIED HEALTH SYSTEM: REVITALIZING THE DEBATE}

In Brazil, public policies regulate the economic, social and environmental issues. ${ }^{8} \mathrm{~A}$ public policy can be considered a device that reveals the duty of the State to guarantee, in the health sphere, the problem-solving capacity of the services, the timely access to care and the care practice. They are created to enhance the system's ability to welcome the health needs and, at the same time, reorganize the practices to further their problem-solving ability and comprehensiveness. ${ }^{9}$

In the Brazilian society, the roots of health policies date back to the start of the previous century, as a result of a statutory proposal. ${ }^{10-11}$ In 1988, the Federal Constitution acknowledged health as a right of citizens and a duty of the State, 
as part of a broad conception of social security that needs to be guaranteed through comprehensive economic and social policies, through the establishment of the SUS. ${ }^{11-12}$ The Constitution guarantees that the health policies be guided by the principles and guidelines of the SUS, ${ }^{13}$ as opposed to the historical tradition of their establishment. These policies have displayed a strongly centralized and vertical shape, concentrating the power at the governmental level, in view of the setting of priorities and the execution of the health services by states and cities. Whether in their formulation or implementation and execution, the health policies are complex processes and sets of multiple interests in the form of the population's true health needs. ${ }^{10}$ The pluralistic nature of the public policy management process entails the role of State in order to strengthen its role as an articulator and catalyst in the practicability of this process. ${ }^{14}$

\section{GENETIC AND GENOMIC DISORDERS AS PUBLIC HEALTH PROBLEMS}

Genetics is the science focused on care delivery to chromosomal alterations, genic diseases and rare syndromes, which can be inherited and affect $3-5 \%$ of the global population. ${ }^{15}$ The term genomics, used for the first time by McKusick and Ruddle, comprises the study of all genes in the human genome, their mutual interactions, with the environment, under the influence of cultural and psychosocial factors. ${ }^{16-17}$ According to these definitions and based on the premises of the directors of the National Institutes of Health and the National Human Genome Research Institute, nine out of the ten main global causes of morbidity and mortality can be considered genetic and genomic diseases, due to the presence of such predispositions. ${ }^{18}$ Therefore, a new genomics-based care model is being proposed, which covers the diagnosis, prevention and therapeutics based on the individual genetic constitution. ${ }^{19}$ It can be considered that genomics-based care is in accordance with comprehensive health care as it comprises the biopsychosocial and spiritual dimension of human beings. Comprehensive care, as one of the principles of the SUS, guides the care lines through which health promotion, prevention and rehabilitation can take place, in view of the complexity and particularities of the health/ disease continuum, the different approaches to the care process and the distinct dimensions of the person who needs care. ${ }^{20}$

In Brazil, actions to organize initial care, diagnosis, complementary tests, referral and counter-referral services, treatment strategies and care longitudinality need to be stimulated so as to attend to genetically predisposed patients or who are at risk of presenting these diseases. ${ }^{5}$ Care needs to be organized and professionals need training to offer welcoming and listen to these people's health needs. ${ }^{21}$ Nevertheless, little importance has been granted to their health needs, as a lack of public policies and insufficient public response are observed in view of the lack of genetics services in the country. ${ }^{5}$ In the attempt to answer these demands, the Ministry of Health proposed the decree that established the NPCCCG. ${ }^{7}$

\section{NATIONAL POLICY FOR COMPREHEN- SIVE CARE IN CLINICAL GENETICS: POSSIBILITIES AND CHALLENGES}

The newly established policy highlights that the diseases with genetic predispositions are more prevalent in developing countries, possibly reflecting the lack of appropriate preventive and therapeutic measures. ${ }^{7}$ It is fundamental to mention the role of prevention, through educational campaigns, the sensitization of the public and health professionals to this issue, which is considered a public health problem. ${ }^{5}$

To put the policy in practice, the decree presupposes primary and specialized care actions. ${ }^{7}$ In primary care, low-complexity procedures can be done, such as the identification, referral and monitoring of individuals and families with problems related to genetic disorders. Specialized care includes the referral centers in clinical genetics and specialized services, with multiprofessional and interdisciplinary monitoring, mediumcomplexity procedures for the cases forwarded by primary care. ${ }^{7}$

With a view to the operation of this policy, some aspects should be highlighted and are needed. The need to establish minimum criteria for the accreditation and qualification of clinical genetics services is emphasized, as well as for support to managers in the regulation, supervision, control and assessment of the care delivered to the users. ${ }^{7}$ In the care context, the 
qualification of the professionals involved in the implantation and implementation of the NPCCCG is essential, through continuing education in health, in line with the comprehensive care principles. In research, the importance of encouraging, coordinating and executing strategic projects is underlined, aimed at studying the cost-effectiveness, efficacy and quality of the genetics services. In database management, the promotion of exchanges with other sectorial information subsystems is highlighted, with a view to improving data production and the democratization of information. ${ }^{22}$

\section{REGULATION OF THE NPCCCG: AN URGENT NEED}

Brazil lives under the aegis of the 1988 Constitution, with represents a landmark in terms of the acknowledgement of social rights. Its article 196 establishes "health as a right of all and a duty of the State". More than twenty years after its enactment, the expanded access to these rights is undeniable. Nevertheless, the evolution of the Brazilian public health scenario still presents challenges to be overcome. First, there is the difficulty to apply general, practicable and equitable standards to such an immense and unequal country. Second, there is the existence of technical-process contents, generally treated in an excessively detailed, bureaucratic and complex manner. ${ }^{13}$

Despite the SUS' attempts to minimize the inequality, improve the access and the comprehensiveness of health care services, since its creation, an important bottleneck for population health remains: the regulation of public policies and their funding. This means that, although the federal constitution broke with the excluding patterns of access to health actions and services, some aspects can make the regulation of these policies unfeasible, such as the interest of organized sectors that encompass a public perspective with little regulatory capacity.

The universal right to health is well established but, among declarations of purposes and the reality, almost insurmountable abysms remain. The service access and consumption offered to individuals with genetic illnesses, or at risk of genetically determined conditions, has revealed to be below expectations, a clear example of the divergence between the constitutional proposal and the reality of Brazilian genetics services.

The insufficiency of an effective governmental response to the problem of birth defects in Brazil is a challenge today. ${ }^{24}$ It should be highlighted that the lack of access and consumption of clinical genetics services has made many users turn to legal measures, based on the premises of a constitutionally guaranteed right. This situation reflects, on the one hand, society's paternalistic view of the State and, on the other, the lack of rules to regulate genetics care in Brazil. ${ }^{24}$

The inclusion of the "genetic mentality" into primary health care should be understood as one of the most effective actions to implement an effective and comprehensive clinical genetics network, ${ }^{5}$ supporting the assertion that comprehensiveness is the principle of the SUS that guides the constitution of care networks. ${ }^{21}$

\section{FINAL CONSIDERATIONS}

The aim in this paper was to reflect on issues related to the regulation of the NPCCCG and, consequently, comprehensive care, access and consumption of clinical genetics services in Brazil. The regulation of the NPCCCG will implement a new care model for the health needs of Brazilian families with or at risk of developing genetically determined diseases. This model presents innovative perspectives, mainly capable of responding to the principles and guidelines of the SUS, especially the principle of comprehensiveness.

The consolidation of the advances expected through the regulation of this policy does not necessarily involve the establishment of referral services, with highly specialized centers and laboratories, but the use of the existing network, based on strategic planning. Brief technical-operational measures can guarantee, even if incipiently at first, but with significant effects in the medium and long terms, clinical genetics care, with positive budgetary impacts.

In primary care, health professionals can use a low-cost and highly effective genomic tool, the collection and recording of the family history for at least three generations, so as to clarify genetic and genomic risks. This permits the recognition of genetic inheritance patterns, addresses the longitudinality principle of care and can 
contribute to the referral and counter-referral system in genetics and genomics. It should be highlighted that, at the primary care level, this care should not be interpreted as a specialty, but as specialized.

In conclusion, the regulation of the NPCCCG needs to prioritize the identification and early diagnosis of individuals at enhanced risk of genetic problems, as well as the improvement of their quality of life all over the country, favoring genomics-based health care.

\section{REFERENCES}

1. Syurina EV, Brankovic I, Probst-Hensch N, Brand A. Genome based health literacy: a new challenge for public health genomics. Public Health Genomics. 2011 Jan; 14(4-5):201-10.

2. Lea DH, Skirton H, Read CY, Willams JK. Implications for educating the next generation of nurses on genetics and genomics in the 21st century. J Nurs Scholarsh. 2011 Mar; 43(1):3-12.

3. Calzone KA, Cashion A, Feetham S, Jenkins J, Prows CA, Williams JK, et al. Nurses transforming health care using genetics and genomics. Nurs Outlook. 2010 Jan; 58(1):26-35.

4. Ministério da Saúde. DATASUS [página na internet]. Informações de Saúde. Óbitos infantis - Brasil: malformações congênitas deformidades e anomalias cromossômicas [acesso 2011 Jul. 21]. Disponível em: http://tabnet.datasus.gov.br/cgi/tabcgi.exe?sim/ cnv/inf10uf.def

5. Horovitz DDG, Cardoso MHC A, Lierena Jr. JC, Mattos RA. Atenção aos defeitos congênitos no Brasil: características do atendimento e propostas para formulação de políticas públicas em genética clínica. Cad Saúde Pública. 2006 Dez; 22(12):2599609.

6. Sociedade Brasileira de Genética Médica (SBGM) [página na internet]. Pela atenção à saúde em genética. 2008. [acesso 2011 jul.3]. Disponível em: http://www.sbgm.org.br/artigos/Artigo_JT_ Gen\%C3\%A9tica_no_SUS_17ago08.pdf

7. Ministério da Saúde (BR). Portaria n. 81, de 20 de janeiro de 2009. Institui no âmbito do Sistema Único de Saúde (SUS). A Política Nacional de Atenção Integral em Genética Clínica. Brasília (DF): MS, 2009.

8. Lucchese PTR, Aguiar DS, Wargas T, Dias-de-Lima L, Magalhães R, Monerat GL. Informação para tomadores de decisão em saúde pública: políticas públicas em saúde. São Paulo (SP): BIREME/OPAS/ OMS; 2002.

9. Righi LB, Pasche DF, Akermam M. Saúde e desenvolvimento: interconexões, re-orientação dos serviços de saúde e desenvolvimento regional [página na internet]. Ijuí (RS) - Santo André (SP); 2006. [acesso 2011 jul. 17]. Disponível em: http://portal.saude.gov.br/portal/arquivos/pdf/ avaliacao_saude_desenvolvimento.pdf

10. Cohn A. O estudo das políticas de saúde: implicações e fatos. In: Campos GWS, Minayo MCS, Akerman M, Drumond Júnior M, Carvalho YM. Tratado de saúde coletiva. Rio de Janeiro (RJ): Ed. Fiocruz; 2006. p.231-58.

11. Machado CV, Baptista TWF, Nogueira CO. Políticas de saúde no Brasil nos anos 2000: a agenda federal de prioridades. Cad Saúde Pública [online]. 2011[acesso 2011 Jul 21]; 27(3):521-32. Disponível em http:/ / www.scielosp.org/pdf/csp/v27n3/12.pdf

12. Paim J, Travassos C, Almeida C, Bahia L, Macinko J. O sistema de saúde brasileiro: história, avanços e desafios. Lancet. 2011 Maio; 6(11)54-8.

13. Ministério da Saúde (BR), Sistema Único de Saúde, Conselho Nacional de Secretários de Saúde. Coleção progestores: para entender a gestão do SUS. Brasília (DF): CONASS; 2011. p.165-180.

14. Cavalcanti BS, Peci A. Além da reforma do aparelho do Estado: para uma nova política de gestão pública. In: Cavalcanti BS, Ruediger MA, Sobreira R. Desenvolvimento e construção nacional: políticas públicas. Rio de Janeiro (RJ): Editora FGV; 2003. p.33-56.

15. Feetham SL, Williams JK. Genetics in nursing. Geneva (CH): International Council of Nurses; 2004.

16. Mckusick VA, Ruddle FH. Toward a complete map of the human genome. Genomics. 1987 Nov; 1(2):103-6.

17. International Society of Nurses in Genetics (ISONG). Genetics genomics nursing: scope \& standarts of practice. Silver Spring (US): American Nurses Association; 2007.

18. Guttmacher AE, Collins FS. Genomic medicine: a primer. N Engl J Med. 2002 Mar; 34(19):1512-20.

19. Jenkins J, Bednash G, Malone B. Bridging the gap between genomics discoveries and clinical care: nurse faculty are key. J Nurs Scholarsh. 2011 Mar; 43(1):1-2.

20. Silva KL, Sena RR. Integralidade do cuidado na saúde: indicações a partir da formação do enfermeiro. Rev Esc Enferm USP [online]. 2008 Mar [acesso 2011 Jul 17]; 42(1):48-56. Disponível em: http://www.scielo.br/pdf/reeusp/v42n1/07.pdf

21. Cecílio LCO. As necessidades de saúde como conceito estruturante na luta pela integralidade e equidade na atenção em saúde. In: Pinheiro R, Mattos RA, organizadores. Os sentidos da integralidade na atenção e no cuidado à saúde. Rio de Janeiro (RJ): Ims, Abrasco; 2001. p.113-26.

22. Conselho Nacional de Secretários de Saúde. Nota Técnica sobre a Política de Atenção Integral em Genética Clínica. Brasília (DF): CONASS; 2008. p.1-7. 
23. Constituição da República Federativa do Brasil de 05 de outubro de 1988. Diário Oficial da República Federativa do Brasil. Brasília, DF: Senado; 1988. Título VIII. Da Ordem Social. Capítulo II. Seção II.
Da Saúde. Art. 196.

24. Novoa MC, Fróes-Burnham T. Desafios para a universalização da genética clínica: o caso brasileiro. Rev Panam Salud Publica. 2011 Nov; 29(1):61-8. 